\title{
Nery Delgado, Pioneer of Archaeological Excavation Methods at the Casa da Moura Cave (Portugal) in 1879-1880
}

\author{
JoÃo Luís CARDoso ${ }^{1,2,3}$ (1) AND NuNo Bicho ${ }^{3}$ (1) \\ ${ }^{1}$ Universidade Aberta, Lisboa, Portugal \\ ${ }^{2}$ Centre of Archaelogical Studies, Oeiras Municipal Council, Portugal \\ ${ }^{3}$ Interdisciplinary Center for Archaeology and Evolution of Human Behaviour \\ (ICArEHB) - Universidade do Algarve, Faro, Portugal
}

Nery Delgado was a key figure in the development of archaeological methods applied to prehistoric sites in Portugal within European archaeology at the end of the nineteenth century. He was the first in Europe to use a grid in his 1879-1880 excavation at the Casa da Moura cave (Óbidos, Portugal). The grid divided the cave into twenty-eight sectors excavated independently and, in each, all archaeological and bioanthropological finds were documented and marked with labels recording depth and excavation units. The 3D information obtained by Nery Delgado features among late nineteenth-century attempts at recording contextual data, a precursor of archaeological methods of data gathering that are used worldwide today. Nery Delgado was, thus, a pioneer of contemporary archaeological excavation methods.

Keywords: Palaeolithic, Portugal, archaeological excavation, methodology, Nery Delgado, Casa da Moura

\section{INTRODUCTION}

The second half of the nineteenth century was crucial for the development and understanding of human evolution and prehistory, including the elaboration of cultural sequences for European prehistory from the Palaeolithic onwards. That process started much earlier with Christian Thomsen in Denmark (Daniel, 1976; Trigger, 1989), quickly spreading to most of northern and central Europe. It was at this time that human evolution and the presence of early humans was finally accepted, overcoming the dominant conservative paradigm championing a short chronology based on Biblical time. Discoveries and scientific innovations were fundamental for that revolution and the acceptance of deep time; publications included, among others, Lyell's Principles of Geology (1830) leading to the acceptance of the concept of Uniformitarianism, the discovery of fossil Neanderthal remains in Forbes Quarry in Gibraltar in 1856 (Menez, 2018), the first publication of the discovery of Neanderthal fossils in Germany (Schaaffhausen, 1858), and the publication of Darwin's Origin of Species (1859).

With the acknowledgement of deep time and early hominins, prehistoric archaeology jumped ahead, and excavations to recover and reconstruct that early past rapidly increased. The work of many scholars was fundamental during this phase, including that of archaeologists and physical 
anthropologists such as Schmerling (17911841) in Belgium, Boucher de Perthes (1757-1844) in France, and Buckland (1784-1856) and MacEnery (1796-1841) in England. Perhaps one of the most relevant figures in this process was William Pengelly because he was able to show the association of early humans in Britain with Pleistocene fauna in his work at various caves in Devon, the best known being Windmill Hill Cave (Brixham) and Kent's Cavern (Torquay), investigated in 1858-59 and 1865-80, respectively (Daniel, 1981: 53; W., 1897: 5; Walker, 2015: 29). This scientific advance was based on Pengelly's introduction of a new excavation technique (Davis, n.d.; Dawkins, 1894). This innovation, applied at Kent's Cavern in 1865, comprised not only the individual excavation of each geological layer but also recording the location of every artefact. Pengelly divided his excavation into blocks, called 'yards', three feet long, one foot wide, and one foot thick (Walker, 2015).

Up to the 1850 s, the artefacts and fossils were the centre of the archaeologists' attention, with excavations generally focusing on gathering artefacts without any particular concern for their provenance. While this was not particularly important on open air sites with single archaeological horizons, it had a major impact in prehistoric cave sites, frequently leading to long sequences being mixed up due to the lack of contextual information recorded during excavation. It was precisely during this period that many findings were made on sites with Palaeolithic sequences and new fossils, such as those of Neanderthal and Gibraltar mentioned earlier. The second half of the nineteenth century was a key turning point in prehistoric archaeology, not only because of such discoveries, but also because of methodological innovations mostly in England but also in the Middle East on sites dating to more recent prehistoric periods.
In Portugal, prehistoric archaeology was virtually non-existent before 1850 . The foundation in 1849 of the Sociedade Archeologica Lusitana (Cardoso, 2018a) and the remodelling of the Geological Commission (Comissão Geológica de Portugat) in 1857 (Antunes, 1986; Cardoso, 2015) brought about major changes. The former was responsible for early large-scale archaeological projects in Portugal, at the Roman site of Troia in the Sado estuary south of Lisbon (Cardoso, 2018a), while the latter was responsible for the excavation of several prehistoric caves in the Portuguese Estremadura as well as in the Muge Mesolithic shellmiddens (Bicho et al., 2015; Cardoso, 2018b).

In the second half of the nineteenth century, archaeological research in Portugal, particularly that of Nery Delgado, who was a member of the Geological Commission, followed very closely the objectives of researchers and institutions of other European regions, namely attempting to document the existence of 'Tertiary Man' (Daniel, 1976: 98), and confirming the antiquity of Palaeolithic human fossils (Cardoso, 2000, 2013; Bicho \& Cardoso, 2018). It is in this context that Nery Delgado undertook the excavation of various cave sites located some $70-100 \mathrm{~km}$ north of Lisbon in the Cesaredas Plateau, near the town of Óbidos. Nery Delgado, like Pengelly in the UK, used new methods in his excavations, including a grid, which is still standard practice today. Our article describes the application of these methods at the cave site of Casa da Moura in 1879-1880.

\section{Nery Delgado (Joaquim Filipe Nery d Encarnação Delgado, 1835-1908)}

Nery Delgado (Figure 1) was a wellknown Portuguese military engineer, geologist, and archaeologist who actively corresponded with his peers at a national 


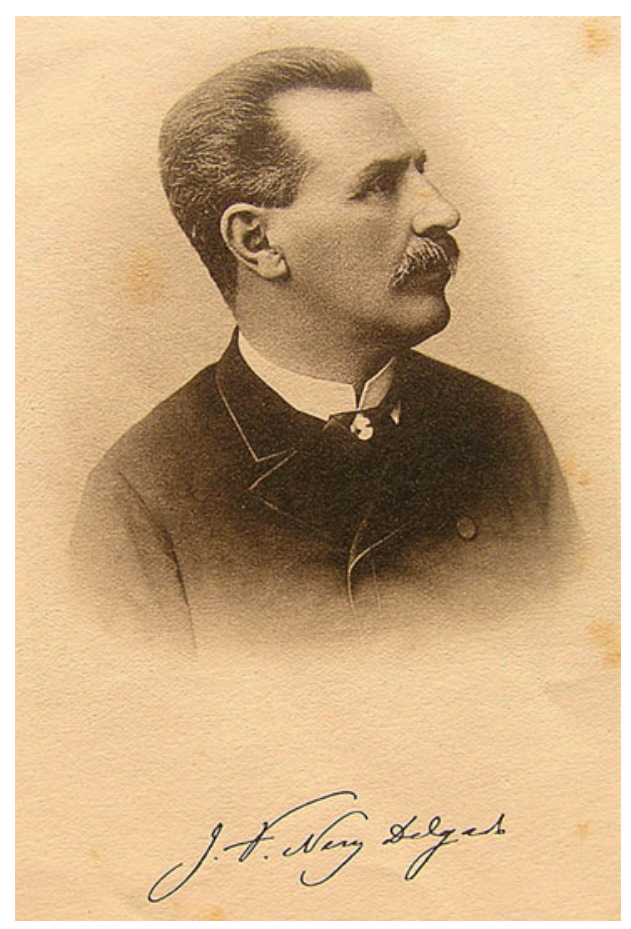

Figure 1. Joaquim Filipe Nery Delgado (18351908) (João Cardoso personal archive).

and international level (Cardoso \& Melo, 2001) and made important contributions to international geological congresses (Carneiro et al., 2014).

Nery Delgado began his career at the Military School and then the Polytechnic School, graduating in Military Engineering from the Military Academy of Portugal in 1855. He was named deputy of the Second Geological Commission of Portugal when it was founded in 1857 , where he showed remarkable activity, taking over its direction in 1882 after the death of Carlos Ribeiro. Delgado was repeatedly promoted in his military career, until he reached the rank of Division General (Lt-General). He continued research in geology until his death in 1908, following a double pneumonia contracted during fieldwork.

As a prominent member of the Royal Academy of Sciences in Lisbon, and of many other scientific societies, he soon became known internationally for the high quality of his scientific work in the field of geology and archaeology, especially on the geology of his country. This activity resulted in the edition of the Geological Map of Portugal, at a scale of 1/500 000, published in 1876, with a second edition two years later. The first draft of this map, coloured by hand, was presented at the Universal Exhibition in Paris in 1867, where it received an award. In addition to the country's geological mapping, he actively contributed to the stratigraphic and palaeontological characterization of Palaeozoic formations in Portugal, studying in particular the Ordovician bilobites of the Beiras group and those related to the Palaeozoic of the Alentejo in southern Portugal.

His contribution to European archaeological studies was equally unique, although he did not consider himself an archaeologist. Nery Delgado, alongside Carlos Ribeiro (1813-1882) and Francisco Pereira da Costa (1809-1889), who were responsible for the Second Geological Commission of Portugal (and the organizations that succeeded it), embody the development and coming of age in Portugal of prehistoric archaeology as scientifically sound and closely linked to geological studies, especially in the fields of stratigraphy and palaeontology. The latter's methods were instrumental in this development, as is clear in Delgado's early publications. Indeed, in Portugal, the spirit that animated the pioneers of the Second Geological Commission did not differ much from that of colleagues beyond the Pyrenees. Nery Delgado and his collaborators were aware of the progress made outside Portugal in the archaeology of early humankind. Their studies, following those in other European countries where prehistoric research had started earlier and was more developed, showed that it was possible to gain knowledge of 
the human past based on material culture buried in the vast archives of caves and open-air sites. These sites were interpreted, as they are today, on the basis of on stratigraphy and typology, revealing the remarkable modernity of the so-called 'Golden Age' of Portuguese archaeology.

\section{The Casa da Moura Site in its Historical CONTEXT}

The Casa da Moura cave is located in the municipality of Óbidos in central Portugal (Figure 2). It is an opening in the Lower Jurassic limestone of the Cesareda plateau, a geomorphological unit with an elongated outline following a general northeastsouthwest orientation that forms part of the northern foothills of the Montejunto mountain range. The cave lies, at about $160 \mathrm{~m}$ asl, on the northern edge of the plateau, some $25 \mathrm{~m}$ away from an escarpment delimitating that plateau. Its entrance, a short sinkhole, overlooks a vast landscape to the north.

From a speleological point of view, the cave's entrance is a narrow, almost vertical chimney, with a maximum width of $3 \mathrm{~m}$ and a height of about $4 \mathrm{~m}$. It gives access to an irregular, somewhat sub-triangular chamber, separated from an inner chamber by a large block fallen from the roof. The two chambers are connected by two narrow side corridors running along the fallen block; these passages were marked in the plan drawn up at the time of Nery Delgado's work but published only now. The two chambers are also connected by an upper gallery. The floor of the first chamber, where the bedrock is presently completely exposed, dips towards the interior of the rocky massif, following the general orientation of the low and irregular roof. By contrast, in the second chamber, the dome-shaped ceiling is about $6 \mathrm{~m}$ high. This roof has a narrow vertical slit that connects with the surface (the socalled 'ear of the Casa da Moura'). The second chamber narrows and slopes down to end in a vertical well, only recently recognized and of no archaeological interest.

Casa da Moura was first explored by Nery Delgado in 1865 , at the same time as Pengelly was working at Kent's Cavern. Delgado's work resulted in a monograph published in 1867, the first-ever such publication in the Iberian Peninsula concerning archaeological work in a prehistoric cave. The excavation's primary purpose was to explore the Pleistocene deposit identified in the cave's first chamber (Delgado, 1867). This was dictated by a significant preoccupation of the geologists of the time, i.e. demonstrating the antiquity of the human species in the caves of western Europe through its coexistence with now extinct species of mammals. This is illustrated by the title of the monograph: Da existencia do Homem no nosso solo em tempos mui remotos provada pelo estudo das cavernas. Primeiro opúsculo. Noticia acerca das grutas da Cesareda [On the existence of Man on our land in very remote times, proven through the study of caverns. First booklet. Note on the Cesareda caves].

This work was developed to pursue the objectives of the second Geological Commission of Portugal, working between 1857 and 1868 (Cardoso, 2018b). The 1865-1866 fieldwork focused on a trench running the full width of the first chamber, uncovering a 2-4 m-long sequence with two major units, of which the bottom metre was of Pleistocene age (Cardoso, 2008: 66). In Delgado's 1867 report, only one human skull was listed; its mandible, recovered from the interface between the Pleistocene and more recent deposits, may have originally come from the Pleistocene deposit or, alternatively, could have been buried in it. These remains were taken for 


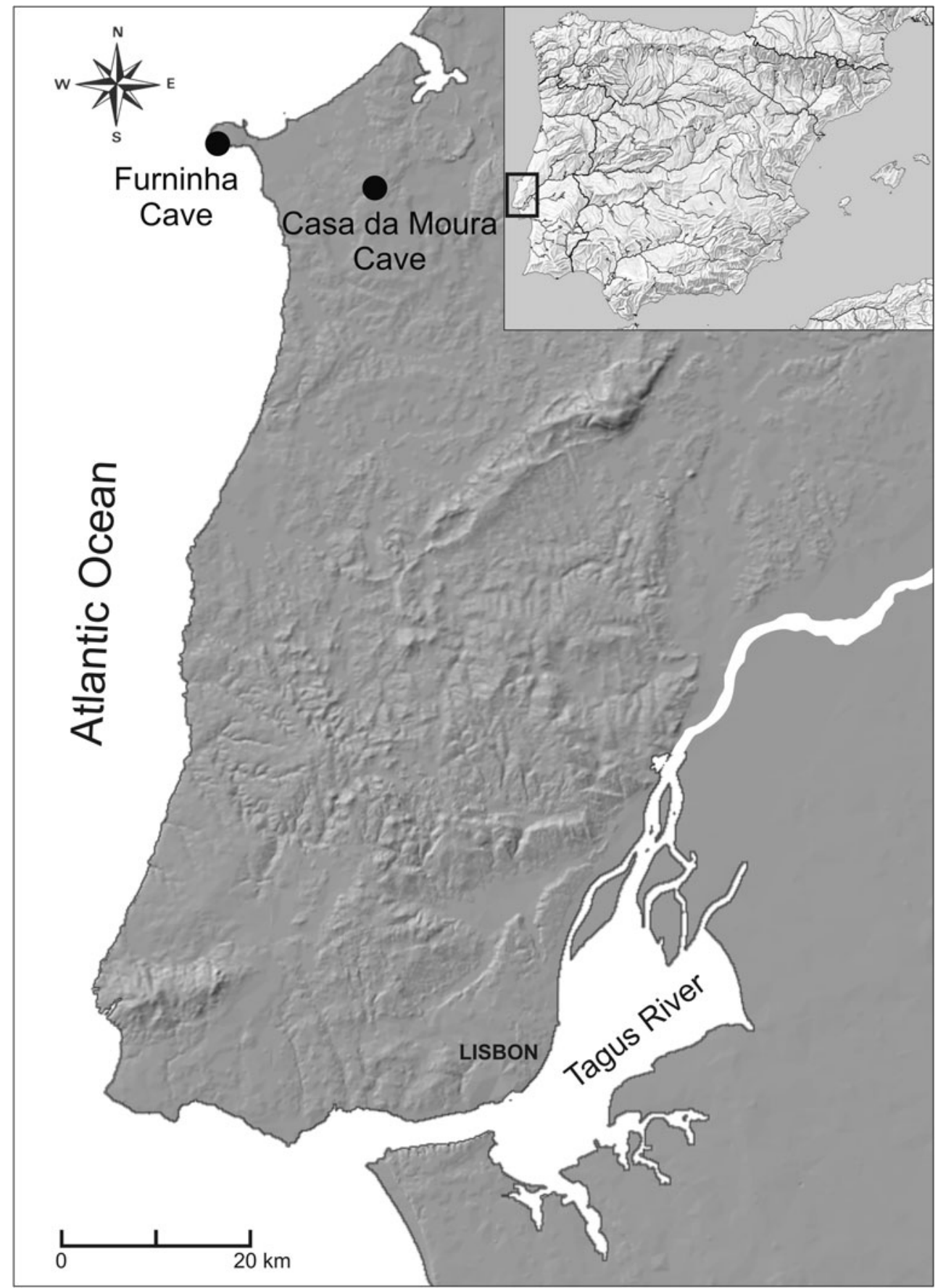

Figure 2. Location of the Casa da Moura and Furninha caves.

study by the physical anthropologist Gisela Asmus to Germany, but they were never returned according to the late Octavio da
Veiga Ferreira (1917-1997). Unfortunately, unless the original skull is found, its age cannot be ascertained. If of Pleistocene age, 
it would be the oldest example of an early Anatomically Modern Human ever found in the world, predating the findings from Cro-Magnon (Zilhão, 1997). The antiquity of this fossil was, however, questioned at the time of its discovery. In 1874, Boyd Dawkins made the following comment: 'A human skull with lower jaw was dug out the deepest part, but, since the matrix has been disturbed, it had probably been interred after the accumulation of the deposit' (Dawkins, 1874: 145).

In 1880, the fifteenth International Congress of Anthropology and Prehistoric Archaeology was held in Lisbon. This was the most important world archaeological meeting at the time (Gonçalves, 1980; Cardoso, 2013). Portugal wanted to show the very significant prehistoric finds unearthed in the country, including the Mesolithic Muge shellmiddens, the flint 'artefacts' documenting the presence of the 'Tertiary Man' in Portugal, and the discoveries of lithic industries associated with Pleistocene and Holocene fauna and human remains in various caves in Estremadura, including the Casa da Moura. Naturally, the Geological Commission intended to show all the materials that had been excavated in those sites but, due to governmental decisions including the demise of the Second Geological Commission in 1869, the materials from Casa da Moura were not available for show at the congress (Cardoso, 2020). As a result, the direction of the Geological Survey (i.e. Carlos Ribeiro and Nery Delgado) decided to return to the cave and recover new materials to show to the participants of the congress. Many of the most influential European prehistorians, including Cartailhac, Choffat, Evans, de Mortillet, de Quatrefages, Shaaffhausen, and Virchow would attend the meeting. It was therefore important to rapidly expand the collections that could be exhibited at this major international convention to highlight the activity taking place in Portugal.
To this end, excavations began simultaneously in the Furninha and Casa da Moura caves in the last few months of 1879 , creating the opportunity to clarify the nature of their Pleistocene deposits as well as other issues, namely the exploration of the upper deposit, still insufficiently studied.

The Casa da Moura campaign of 18791880 led to the full excavation of what was left of the lower deposit, dating to the Pleistocene period and in which human remains were scarce and possibly intrusive, and of the upper deposit described as 'upper rubble' with Neolithic/Chalcolithic burials. Unlike the previous campaign of 1865-1866, the objectives of the 18791880 season gave great importance to the exploration of the top layer, a poorly consolidated, blackish-brown sediment with abundant human remains and Neolithic and Chalcolithic artefacts, whose presence had previously been neglected.

The 1879-1880 excavation of Casa da Moura was carried out in the cave's first chamber, deepening and widening the trench excavated in the 1860s. The stratigraphy in the first chamber, the one with the highest potential (Figures 3 and 4; Delgado, 1867), confirms the results obtained in 1865-66. Two main deposits were encountered: a top layer, dubbed 'upper rubble', was a brownish-black sediment with abundant human remains and archaeological material of Neolithic and more recent date belonging to a collective burial site; and an earlier deposit, separated from the previous layer by an important set of stalagmitic crusts, interstratified with a reddish sandy-clay. This latter lay directly on a stalagmitic mantle over the bedrock and was characterized by abundant rabbit and bird remains associated with some Palaeolithic stone and bone tools (Cardoso \& Gomes, 1994; Zilhão, 1997). At the time, these artefacts were not separated from the more recent archaeological remains. This sequence was 


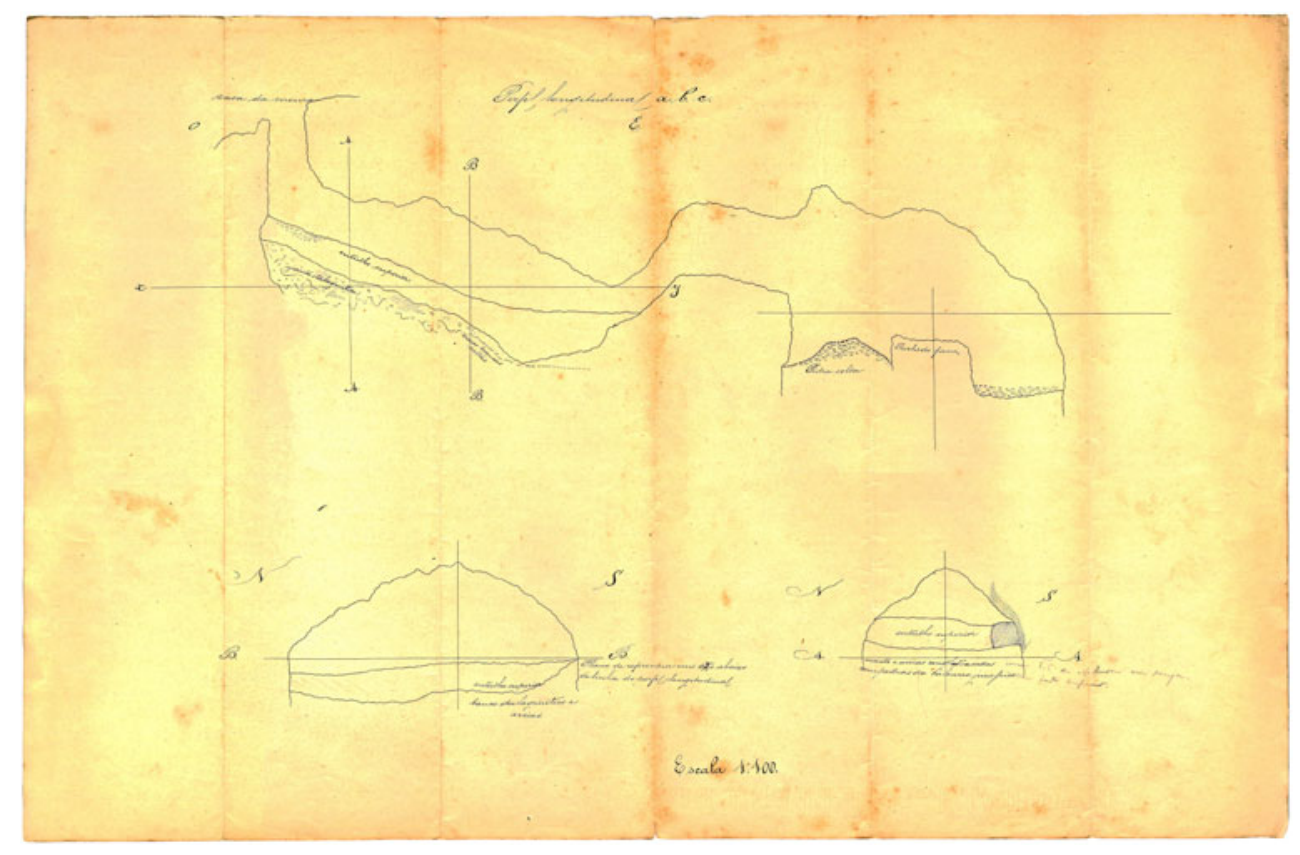

Figure 3. Casa da Moura. Longitudinal section of the cave, showing the extent of the two almost completely excavated deposits, along with two cross-sections showing the thickness of the deposits. Original survey by Miguel Pedroso, reviewed by Nery Delgado (João Cardoso personal archive).

later confirmed by the excavation of a small remnant of the deposit near the entrance of the cave, which had been left untouched (Straus et al., 1988).

The operation met with success, as attested by the reports (Relatório) of the
Comissão dos Trabalhos Geológicos for the financial year 1879-1880 (published 1881) and 1881-1882. The later report illustrates the importance of that work: 'Another Cesareda cave, known as Casa da Moura, which, as mentioned in the

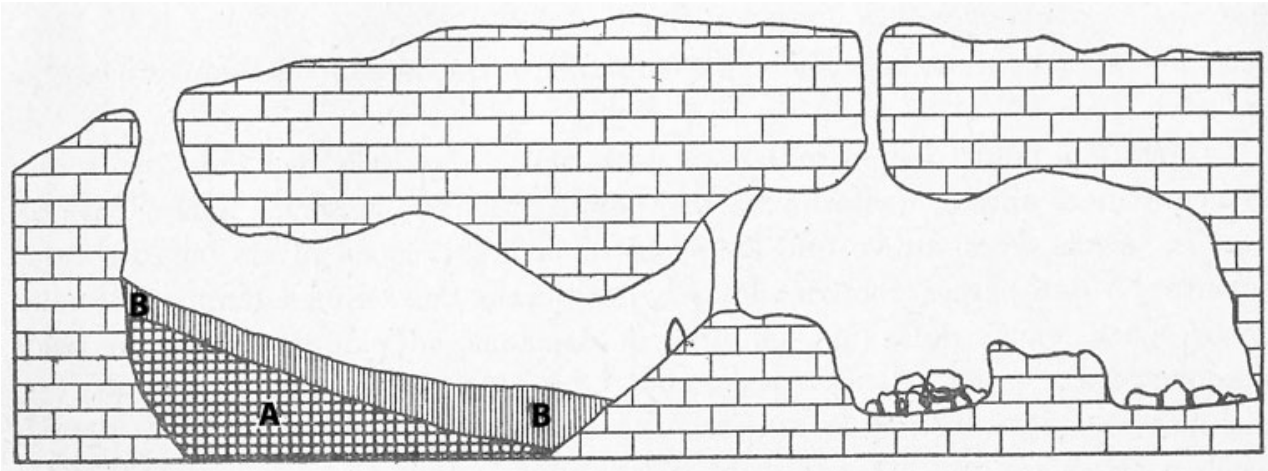

Figure 4. Profile of Casa da Moura based on the drawing illustrated in Figure 3. A: Pleistocene deposit; B top layer with Neolithic and later human burials. After Georges Zbyszewski. 
previous report, yielded an outstanding assemblage, especially human remains and Neolithic industries, was also thoroughly studied by the same Section Assistant and the recovered exemplars were duly classified and catalogued' (authors' translation of Relatório, 1882: 15). The results from the excavation of both caves were briefly but quickly published in June 1880, on completion of the excavations (Delgado, 1880). Two almost complete skulls from Casa da Moura (Oliveira, 1884) and the detailed results obtained at Furninha at the same time were presented to the International Congress in Lisbon in the same year (Delgado, 1884). This gave rise to a heated debate, especially concerning anthropophagy (the consumption of human remains), firmly endorsed by Nery Delgado (Delgado, 1884).

Despite the large quantity and diversity of the archaeological remains recovered, only a few specimens were presented at the time (Cartailhac, 1886), and almost the entire collection remained unpublished until 2002 (Carreira \& Cardoso, 2002) when the remains kept at the Geological Museum of the National Laboratory of Energy and Geology (LNEG) and the National Museum of Archaeology were described.

\section{The Excavation And Methodological InNovations}

It was frequent in Portugal during the nineteenth century and up to the midtwentieth century to have labourers carrying out the excavation with only sporadic visits by those responsible. It was during these visits that the excavation strategy and methods were devised. This was the case at Casa da Moura and of Nery Delgado, who entrusted the work to Miguel Pedroso, a field assistant (colector) of the Geological Commission, as attested by letters sent by Pedroso to Nery Delgado and to the administrative officer of the Commission, Carlos Calderon (see Cardoso, 2020 for a full transcription of all the letters exchanged between Miguel Pedroso, Nery Delgado, and Carlos Calderon).

These letters provide essential information on the progress of the work, and the difficulties encountered, illustrating that Nery Delgado's role was mostly to provide written guidance for the implementation of the excavation. More importantly for our discussion are indications of the innovative methods deployed by Nery Delgado during the excavation. It was this set of letters, recovered by Octavio da Veiga Ferreira in 1975/76 from the Geological Museum waste as they were being thrown away, together with documents concerning the 1879-1880 campaigns at the Casa da Moura cave, that enabled us to reconstruct the work carried out at Casa da Moura in 1880 during the months leading up to the 1880 International Congress.

In the 1865-1866 campaign, the excavation was already rigorously conducted, with records of the depth of each finding, as stated by Nery Delgado: 'By excavating the rubble, layer after layer, it was easy enough for us to recover all these objects, always knowing at which depth they had been found throughout the cave' (Authors' translation of Delgado, 1867: 46). This was taken even further in the 1879-1880 campaign, for which the documents demostrate the scientific quality, highly innovative for the time, of the excavation. In particular, a letter dated 2 January 1880 , sent by the excavator, Miguel Pedroso, to Nery Delgado when the excavation was already well underway, contains the ground plan of the first chamber of the cave, with the following indication: 'Remetto o desenho da gruta devedida em 28 partes' [I am sending the drawing of the 


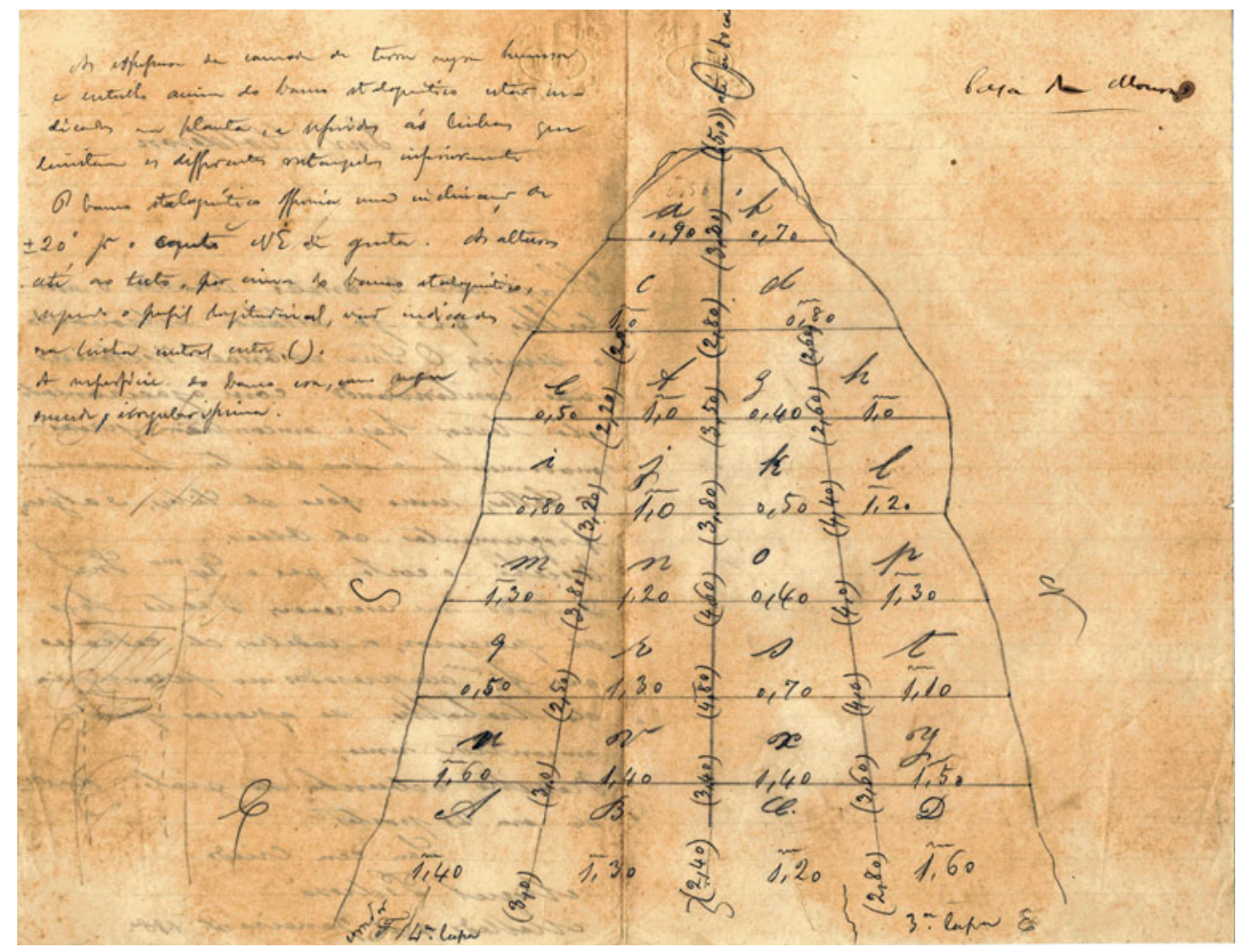

Figure 5. Casa da Moura. Pencil drawn plan of the cave, on the back of a letter dated 2 January 1880 addressed to Carlos Calderon. The twenty-eight sectors in the first chamber of the cave are indicated. Note the cave entrance, through a vertical well, situated at the top of the central axis of the drawing; the precise distances of each grid sector; indications of the third lapa (chamber) to the north, and fourth lapa, to the south (lower right and left sections of the diagram, respectively), on both sides of the large block fallen from the roof (in the lower section of the drawing to the right and left), which separated the first chamber from the second (João Cardoso personal archive).

cave, divided into 28 parts]. The back of this letter shows a very detailed pencil drawing of the cave's main chamber (Figure 5), with measurements of the sides of the grid. An observation written in pencil by Nery Delgado, next to the ground plan view and postdating it, clarifies the meaning of the measurements included in the drawing:

'A espessura da camada de terra negra humosa e entulho acima do banco stalagmitico estão indicados na planta, e referidos às linhas que limitam os differentes rectangulos inferiormente.
$O$ banco stalagmitico offerecia uma inclinação de $\pm 20^{\circ}$ para o canto N.E. da gruta. As alturas até ao tecto, por cima do banco stalagmitico, segundo o perfil longitudinal, vão indicados na linha central entre (). A superficie do banco era, como sempre succede irregularissima.' (in Cardoso, 2020: 135)

['The thickness of the layer of black humic soil and rubble above the stalagmitic crust are indicated in the plan, in relation to the lines delimiting the lower side of the various rectangles.

The stalagmitic crust had a dip of \pm $20^{\circ}$ towards the N.E. corner of the 
cave. The height of the roof, along the longitudinal profile, is indicated on the central line in () The surface of the crust was very irregular, as always.'] (translation of the letter published in Portuguese in Cardoso, 2020: 135)

We therefore conclude that Nery Delgado instructed Miguel Pedroso to make a detailed drawing, including variations in the thickness of the archaeological layers corresponding to the Neolithic and Chalcolithic burials, as observed in each excavated grid sector, as well as variations in the height of the cave roof. These data were gathered directly by Pedroso during excavation, making him the author of one of the most important documents of the early days of Portuguese archaeology, highlighting the valuable role field assistants played in the gathering of scientific knowledge, often forgotten or underestimated (Carneiro, 2005). The twenty-eight grid sectors identified in the plan by capital and small letters, according to a predefined orthogonal grid, are similar in size, as can be seen from the numbers written on the plan; these sectors were excavated in successive predefined artificial levels.

It is not easy for us to appreciate how harsh working conditions were, bearing in mind the rudimentary means available at the time, when the lighting of the cave was provided only by torches and candles. This grid, whose existence is only now confirmed by the newly-recovered documents, had been previously suspected to have existed on the basis of information present on the labels associated with the finds (Cardoso, 2008: 66). The collection from the 18791880 work deposited at the Geological Museum shows this type of label on the back of some pieces: a capital or small letter, followed by a measurement in metres (ranging from $0.20 \mathrm{~m}$ to $2.0 \mathrm{~m}$ ). A second label, if present, refers to a date corresponding to the time of recovery (Figure 6).
That the sectors recorded in the preserved ground plan were dug separately, sector by sector, is confirmed independently by the inventory of archaeological and anthropological remains listed in a set of fifty-four notebooks, where the depth of the finds was also logged. All entries were written by Nery Delgado, to varying degrees of detail. The first five notebooks contain observations and notes related to the excavation, probably in preparation for writing a second monograph that Delgado apparently intended to write but never completed.

The remaining notebooks contain a systematic inventory of all finds with information on the excavated grid sectors and the respective recovery depths. This was a painstaking task conducted over a long period and with extreme thoroughness, revealing the scientific standing of its author. This record provides the location of the most important archaeological items found at the time. The bioanthropological background of the author is also shown in this inventory since it summarizes the results obtained from the human bone fragments by location and depth.

Publications started to appear soon after the 1880 international congress in Lisbon (Bensaúde, 1884; Cartailhac, 1886). Only more recently have the bioanthropological remains been published, and dated to the Early Neolithic and up to the Bronze Age (Carreira \& Cardoso, 2002; Antunes et al., 2009; Carvalho \& Cardoso, 2011). The faunal remains were published in 1993 (Cardoso, 1993), while the Palaeolithic artefacts were the object of a detailed revision (Zilhão, 1997).

The conservation and storage of the artefacts, fauna, and human remains have an interesting history. There are a few archaeological pieces from the 1865-1866 excavations in the Portuguese National Museum of Archaeology in Lisbon (Cardoso \& Carreira, 1996). The human 


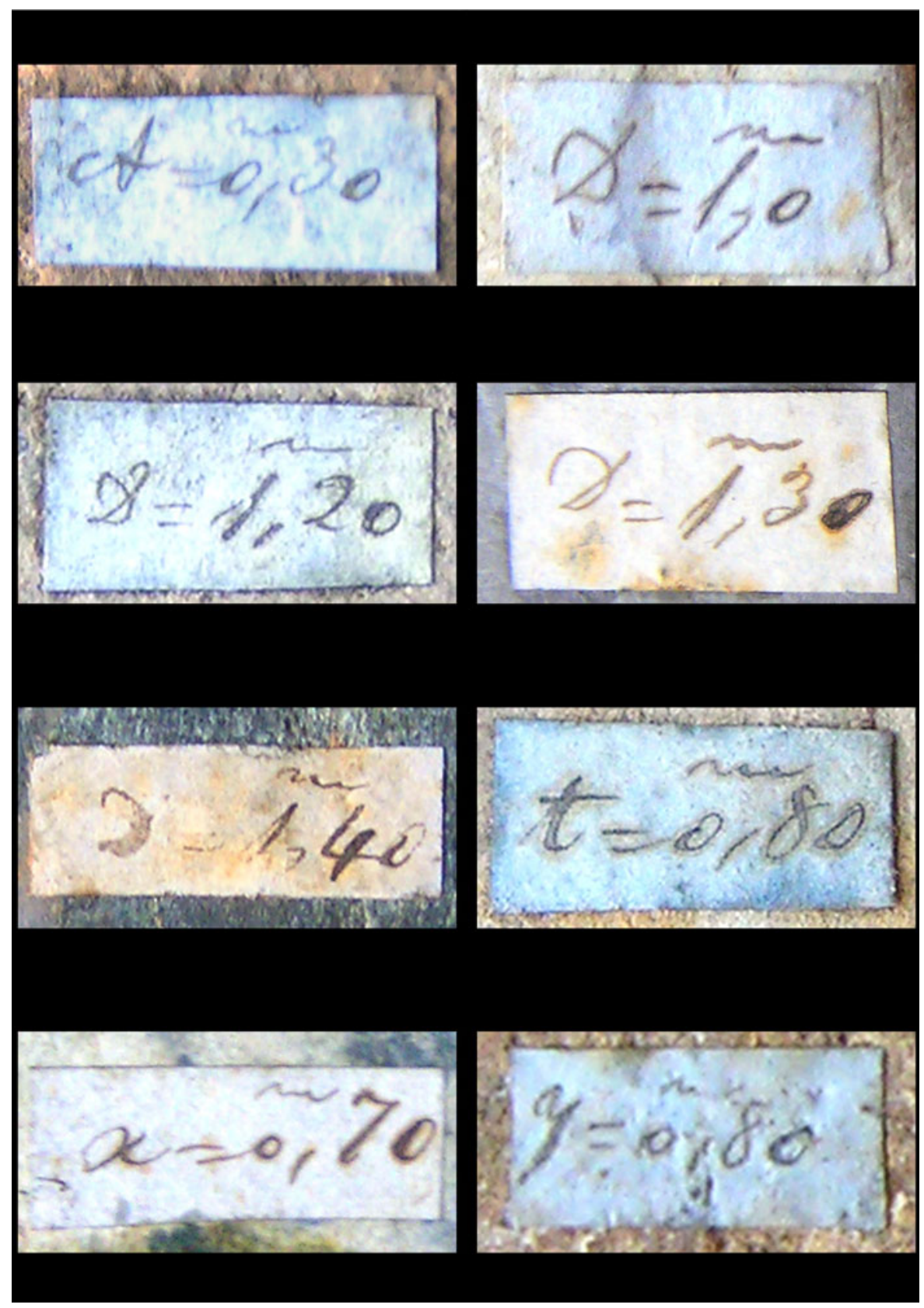

Figure 6. Examples of Casa da Moura original labels from 1879-1880, showing a letter and a number, corresponding to grid location and depth. By permission of the Geological Museum of the National Laboratory of Energy and Geology (LNEG; photographs by João Cardoso).

remains recovered in 1865-1866 were kept at the Polytechnic School in Lisbon but were destroyed in a fire in 1978, except for the skull taken to Germany, as mentioned above. The assemblages (archaeological and human bones) from the 1879-1880 excavations were kept in the Geological Museum in Lisbon, the direct successor of 


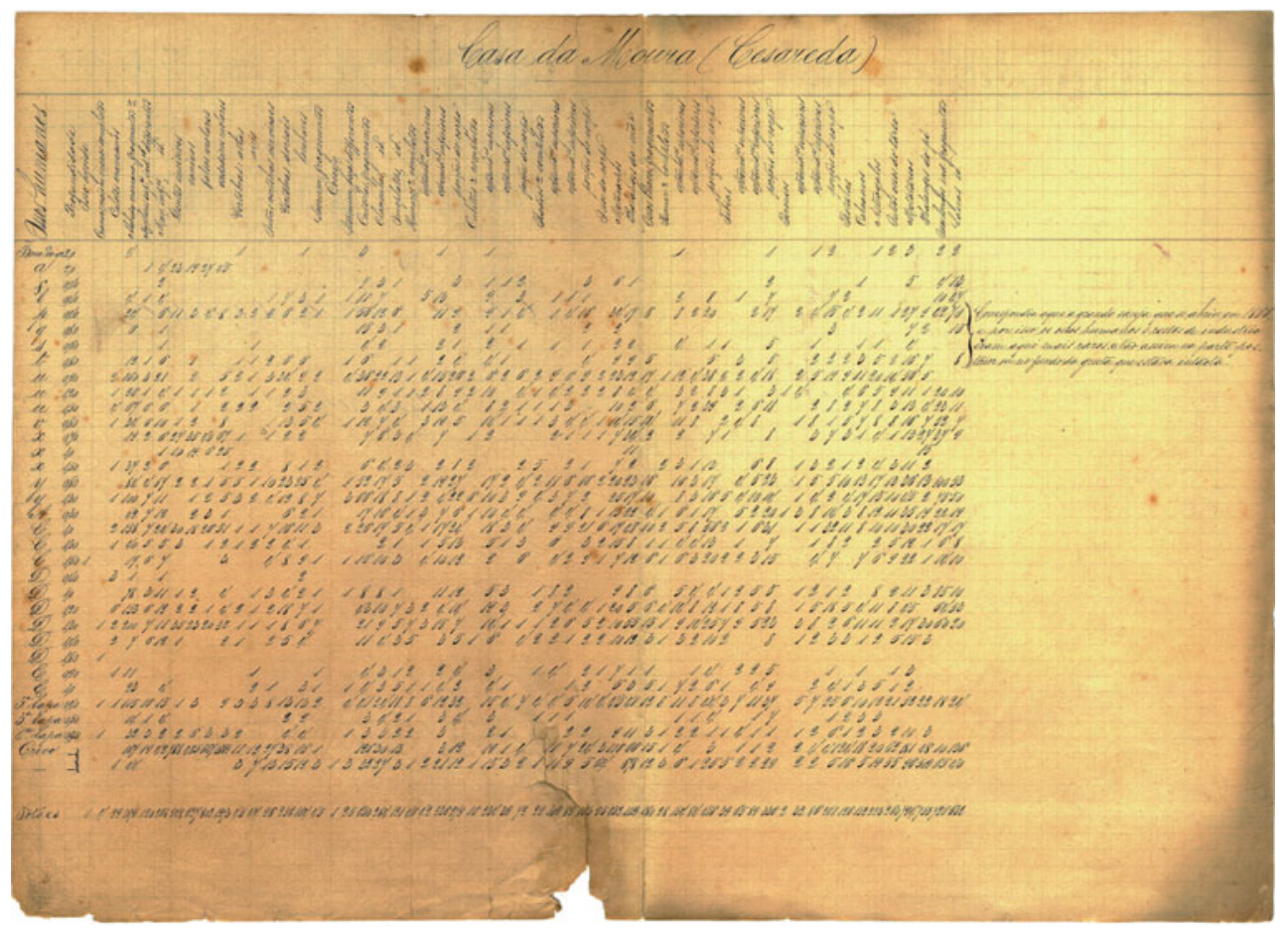

Figure 7. Original inventory of the human remains listed according to provenance (Joano Cardoso personal archive).

the Geological Commission Museum, where they remain today.

As was common at the time, museums exchanged archaeological items. The Ashmolean Museum, in Oxford, and the British Museum received such artefacts from the Casa da Moura site, sent respectively to John Evans and Henry Hoyle Howorth in 1889 and 1890 (Cardoso \& Melo, 2001).

The documentation now published clearly shows the methodological innovations of the fieldwork developed by Nery Delgado. These innovations, exceptional for the time, included the meticulous plan of the area excavated at Casa da Moura, based on a detailed grid imposed on the surface of the cavern. In addition, Nery Delgado gathered accurate information on the thickness of the deposits and the elevation of the cave chamber in each excavation block. Finally, the 3D provenance of all artefacts, fauna, and human remains was recorded and related to the plan of the cave as well as to each excavated natural and artificial layer (Figure 7).

Some of the items kept in the Geological Museum in Lisbon still retain their labels, with information on provenance and depth. This information makes it possible to reconstruct the spatial and vertical distribution of the material excavated almost 150 years ago, almost as accurately as if a modern total station had been used.

The work carried out by Nery Delgado in 1879-1880 at the Casa da Moura cave, assisted by Miguel Pedroso, shows that the excavation, but also the study and inventory of the archaeological, anthropological, and faunal remains, were conducted to a high scientific standard. This seminal work was served by a critical spirit, methodological 
approach, and innovative character, a rather exceptional feat at the time.

\section{Final Considerations}

The objective of the present study is to highlight the innovative methodology adopted by Nery Delgado in the 18791880 excavation of the Casa da Moura cave. The documents now published reflect the pioneering spirit of this Portuguese geologist and archaeologist in the application of a method still in use today: the implementation of an excavation grid, setting up an orthogonal reference system that makes it possible to record the position of any item.

Nery Delgado's archaeological work at Casa da Moura, begun in 1865-1866 and continued in 1879-1880, was the first excavation of a cave with prehistoric occupation ever carried out in the Iberian Peninsula. The main objective of the 1865-1866 campaign was to document the association of stone tools with Pleistocene faunas. The excavation was carried out by a field assistant, Miguel Pedroso, who was instructed by Nery Delgado to establish a grid, which he successfully adapted to the geometry of the cavity. Setting up this reference system on the ground involved following an axis of symmetry defined by a line dividing the cave's gallery into two roughly equal parts, from which a system of parallel orthogonal lines was developed, resulting in the definition of the basic excavation areas identified by a letter. These areas were excavated according to predefined artificial levels, which feature on labels containing a number in metres.

This was not without precedent: William Pengelly had already adopted a similar system, based on sediment blocks named 'yards', at Kent's Cavern in 1865, resulting in the vertical overlap of successive yards (Davis, n.d.; McFarlane \& Lundberg, 2005; Walker, 2015).
Compared to William Pengelly's methodology, the main difference was that the reference system adopted by Nery Delgado was easier to use, involving a more regular grid, identifying roughly sub-quadrangular basic units with areas readily adjustable to the pre-existing geometry of the cave. Indeed, the strict and elongated excavation units defined by Pengelly were difficult to apply in the excavation of a cave and could be advantageously replaced, in practical terms, by isometric volumes such as those adopted by Nery Delgado, and still used today on many archaeological excavations. Since there is no indication in any of Delgado's works and letters that he was aware of Pengelly's methods, it is likely that the two developed their methods independently.

The field methods used in Iberia at the time were lagging behind those of other regions in Europe, particularly northern Europe. Spain was even less advanced than Portugal, probably because the Portuguese government took an interest in prehistoric archaeology at the time, through the Geological Commission and the various official institutions of the second half of the nineteenth century.

Delgado's original contribution to the methodology of archaeological fieldwork, using a grid, artificial excavation spits, the 3D provenance of artefacts and human remains, and systematic inventories of the assemblages by sector and according to the depth of the excavation as it progressed, clearly places him among the pioneers of contemporary archaeology. $\mathrm{He}$ is one of the most remarkable nineteenth-century European archaeologists, only now rescued from oblivion.

\section{Acknowledgements}

We wish to thank José Carlos Henrique for the preliminary transcription of the 
documentation on which this article is based and for his dedication in undertaking such an arduous task, completed with his customary commitment and interest. We are grateful to Miguel Ramalho and José António Anacleto for obtaining the photographs of exemplars from Casa da Moura kept at the National Laboratory of Energy and Geology (LNEG)'s Geological Museum; to Ana Carneiro for providing information of the collectors' correspondence that are kept at LNEG's archives; to João Zilhão, for his interest in this study and for providing bibliographic information on William Pengelly's excavation of Kent's Cavern; and to Armando Lucena for an earlier English version of the Portuguese manuscript. Finally, we wish to thank Milena Carvalho for help with revising the English manuscript as well as to Madeleine Hummler for a full English review of the accepted paper.

\section{REFERENCES}

Antunes, M.T. 1986. Sobre a história da Paleontologia em Portugal. In: M.T Antunes, ed. História e desenvolvimento da Ciência em Portuga 2. Lisboa: Academia das Ciências de Lisboa, pp. 773-814.

Antunes, M.T., Cardoso, J.L. \& Cunha, A.S. 2009. Espólio humano da Gruta da Casa da Moura (Cesareda): observações osteológicas crânio-faciais. Estudos Arqueológicos de Oeiras, 17: 175-221.

Bensaúde, A. 1884. Note sur la nature minéralogique de quelques instruments de pierre trouvés en Portugal. In: Congrès International d'Anthropologie et d'Archéologie Prébistoriques. Compte-rendu de la neuvième session (Lisbonne, 1880). Lisbonne: Typographie de l'Académie Royale des Sciences, pp. 682-697.

Bicho, N. \& Cardoso, J.L. 2018. O estudo do paleolítico superior e do mesolítico em Portugal: uma perspectiva historiográfica. Estudos Arqueológicos de Oeiras, 24: 67-98.

Bicho, N., Detry, C., Price, T.D. \& Cunha, E. 2015. Muge 150th: The 150th Anniversary of the Discovery of Mesolithic
Shellmiddens, Volume 1. Newcastle upon Tyne: Cambridge Scholars Publishing.

Cardoso, J.L. 1993. Contribuição para o conhecimento dos grandes mamiferos do Plistocénico Superior de Portugal. Oeiras: Câmara Municipal de Oeiras.

Cardoso, J.L. 2000. As investigações de Carlos Ribeiro e de Nery Delgado sobre o "Homem Terciário": resultados e consequências na epoca e para além dela. Estudos Arqueológicos de Oeiras, 8: 33-54.

Cardoso, J.L. 2008. Joaquim Felipe Nery Delgado, arqueólogo. In: M. Ramalho, ed. Nery Delgado (1835-1908), Geólogo do Reino. Lisboa: Museu Geológico \& Centro de História e Filosofia das Ciências, UNL.

Cardoso, J.L. 2013. Carlos Ribeiro, a "Breve noticia acerca do terreno quaternário de Portugal", e a questão do homem terciário em Portugal. Estudos Arqueológicos de Oeiras, 20: 27-88.

Cardoso, J.L. 2015. A investigação da antiguidade do Homem no Portugal de Oitocentos: um contributo para a História da Ciência. Estudos Arqueológicos de Oeiras, 22: 9-42.

Cardoso, J.L. 2018a. Aspectos das explorações em Tróia da Sociedade Arqueológica Lusitana com base em documentação inédita. Estudos Arqueológicos de Oeiras, 24: 483-502.

Cardoso, J.L. 2018b. Primórdios dos estudos pré-históricos em Portugal: os concheiros mesolíticos de Muge (Salvaterra de Magos) e a Memória pioneira de Francisco António Pereira da Costa sobre o concheiro do Cabeço da Arruda. In: J.E. Franco, ed. Obras Pioneiras da Cultura Portuguesa. Primeiros textos de pré-história, história e heráldica, vol. 2. Lisboa: Círculo de Leitores, pp. 91-112.

Cardoso, J.L. 2020. A primeira escavação arqueológica metodologicamente moderna foi realizada em Portugal em 1879/1880: a intervenção de Nery Delgado na gruta da Casa da Moura (Óbidos, Portugal). Estudos Arqueológicos de Oeiras, 26: 123-242.

Cardoso, J.L. \& Carreira, J.R. 1996. Um conjunto de litografias arqueológicas inéditas da Comissão Geológica de Portugal. Comunicações do Instituto Geológico e Mineiro, 82: 145-168.

Cardoso, J.L. \& Gomes, M.V. 1994. Zagaias do Paleolítico superior de Portugal. Portugalia, 15: 9-31. 
Cardoso, J.L. \& Melo, A.Á. De 2001. Correspondência anotada de Carlos Ribeiro e de Nery Delgado: contribuição para a história da Arqueologia em Portugal. Comunicações do Instituto de Geologia e Mineiro, 88: 309-346.

Carneiro, A. 2005. Outside Government Science, 'Not a single tiny bone to cheer us up!' The Geological Survey of Portugal (1857-1908), the Involvement of Common Men, and the Reaction of Civil Society to Geological Research. Annals of Science, 62: 141-204.

Carneiro, A., Mota, T.S. \& Leitão, V. 2014. $O$ chão que pisamos: a geologia ao serviço do estado (1848-1974). Lisboa: Colibri.

Carreira, J.R. \& Cardoso, J.L. 2002. A gruta da Casa da Moura (Cesareda, Óbidos) e sua ocupação pós-paleolítica. Estudos Arqueológicos de Oeiras, 10: 249-361.

Cartailhac, E. 1886. Les âges prébistoriques de l'Espagne et du Portugal. Paris: Ch. Reinwald.

Carvalho, A.F. \& Cardoso, J.L. 2011. A cronologia absoluta das ocupações funerárias da gruta da Casa da Moura (Óbidos). Estudos Arqueológicos de Oeiras, 18: 393-405.

Daniel, G.E. 1976. A Hundred and Fifty Years of Archaeology. London: Duckworth.

Daniel, G.E. 1981. A Short History of Archaeology. London: Thames \& Hudson.

Darwin, C. 1859. On the Origin of Species by Means of Natural Selection, or Preservation of Favoured Races in the Struggle for Life. London: John Murray.

Davis, W. n.d. William Pengelly, F.R.S. [online] [accessed 6 April 2020]. Available at: <https://pengellytrust.org/william-pengelly-f-r-s/>

Dawkins, W.B. 1874. Cave Hunting: Researches on the Evidence of Caves Respecting the Early Inhabitants of Europe. London: Macmillan.

Dawkins, W.B. 1894. William Pengelly. Nature, 49: 536-537.

Delgado, J.F.N. 1867. Da existencia do homem no nosso solo em tempos mui remotos provada pelo estudo das cavernas: noticia ácerca das Grutas de Cesareda. Lisboa: Academia Real das Sciencias.

Delgado, J.F.N. 1880. Les grottes de Peniche et Casa da Moura, Portugal. Station et sépulture néolithique. Materiaux pour l'bistoire primitive et naturelle de l'Homme, 2: 241-247.

Delgado, J.F.N. 1884. La grotte de Furninha à Peniche. Compte-rendu de la neuvième session (Lisbonne 1880). Lisbonne: Typographie de l'Académie Royale des Sciences, pp. 207-279.

Gonçalves, V.S. 1980. O IX Congresso Internacional de Antropologia e Arqueologia Pré-Históricas (Lisboa, 1880): uma leitura, seguida da" crónica" de Bordalo Pinheíro. Lisboa: Centro de História da Universidade de Lisboa.

Lyell, C. 1830. Principles of Geology. London: John Murray.

McFarlane, D.A. \& Lundberg, J. 2005. The 19th Century Excavation of Kent's Cavern, England. Journal of Cave and Karst Studies, 67: 39-47.

Menez, A. 2018. Custodian of the Gibraltar Skull: The History of the Bibraltar Scientific Society. Earth Sciences History, 37: 34-62. https://doi.org/10.17704/19446178-37.1.34

Oliveira, F.D.P. 1884. Notes sur les ossements humains qui se trouvent dans le Musée de la Section Géologique de Lisbonne. Congrès International d'Anthropologie et d'Archéologie Prébistoriques (Lisbonne, 1880). Compte-rendu de la neuvième session. Lisbonne: Typographie de l'Académie Royale des Sciences, pp. 291-305.

Relatório 1881. Relatorio dos trabalhos geodésicos, topographicos, hydrographicos e geológicos do Reino pertencente ao anno económico de 1879-1880. Lisboa: Imprensa Nacional.

Relatório 1882. Relatorio do anno económico de 1880-1881 da Direcção-Geral dos trabalhos geodesicos, topographicos, hydrographicos e geologicos do Reino. Lisboa: Imprensa Nacional.

Schaaffhausen, D. 1858. Zur Kenntnis der ältesten Rassenschädel. Berlin: n.p.

Straus, L., Altuna, J., Jakes, M. \& Kunst, M. 1988. New Excavations in Casa da Moura (Serra d'El Rei, Peniche) and at the Abrigos de Bocas (Rio Maior), Portugal. Arqueologia (Porto), 18: 65-95.

Trigger, B.G. 1989. A History of Archaeological Thought. Cambridge: Cambridge University Press.

W., H.B. 1897. A Memoir of William Pengelly, of Torquay, FRS, Geologist, with a Selection from his Correspondence. Nature, 57: 4-6.

Walker, E.A. 2015. Discoveries in Devon: The Works of Father John MacEnery and William Pengelly. Lithics, The Journal of the Lithic Studies Society, 30: 25-33. 
Zilhão, J. 1997. O Paleolitico Superior da Estremadura portuguesa. Lisboa: Colibri.

\section{BiograPhical Notes}

João Luís Cardoso is Professor of Archaeology at Universidade Aberta. He finished his $\mathrm{PhD}$ in Palaeontology of Pleistocene Large Mammals at Universidade Nova de Lisboa in 1992. He is an expert in zooarchaeology, history of archaeology, and the Iberian Copper Age. Cardoso is currently the Vice-rector of Universidade Aberta.

Address: Universidade Aberta, Rua Silva Porto, 16, Funchalinho, 2825-834 Trafaria, Portugal; Centro de Estudos Arqueológicos do Concelho de Oeiras (Câmara Municipal de Oeiras); Interdisciplinary Center for Archaeology and Evolution of Human Behaviour (ICArEHB), Faculdade das Ciências Humanas e Sociais, Universidade do Algarve, Campus de Gambelas, 8005139 Faro, Portugal. [email: cardoso18@netvisao.pt]. ORCID: 0000-0003-2234-2266

Nuno Bicho received his $\mathrm{PhD}$ from Southern Methodist University, Dallas, Texas, in 1992 and is now Professor of Archaeology at Universidade do Algarve. $\mathrm{He}$ is currently director of the Interdisciplinary Center for Archaeology and Evolution of Human Behaviour (ICArEHB). His research focus on Stone Age archaeology, both in Iberia and Africa, particularly in Mozambique and Sudan.

Address: Interdisciplinary Center for Archaeology and Evolution of Human Behaviour (ICArEHB), Faculdade das Ciências Humanas e Sociais, Universidade do Algarve, Campus de Gambelas, 8005139 Faro, Portugal. [email: Nbicho@ualg. pt]. ORCID: 0000-0001-9655-0549

\section{Nery Delgado, un pionnier des méthodes de fouilles archéologiques dans la grotte de Casa da Moura (Portugal) en 1879-1880}

Nery Delgado a joué un rôle important dans le développement des techniques de fouille employées sur les sites prébistoriques portugais à la fin du XIXe siècle, alors que l'archéologie prenait son essor en Europe. Pour la première fois en Europe, il utilisa un système de carroyage sur ses fouilles de 1879-1880 dans la grotte de Casa da Moura (Óbidos, Portugal). Ce carroyage divisait la grotte en vingt-huit secteurs décapés indépendamment, les données archéologiques et anthropologiques étant documentées dans chaque secteur et enregistrées sur des étiquettes sur lesquelles figuraient la profondeur des objets récupérés et le secteur fouillé. Cette méthode d'enregistrement en trois dimensions dimensions fut un précurseur des techniques de fouille actuellement suivies dans le monde entier. Nery Delgado fut ainsi un pionnier des pratiques modernes dont limportance vient seulement d'être reconnue. Translation by Madeleine Hummler

Mots clés: Paléolithique, Portugal, fouilles archéologiques, méthodologie, Nery Delgado, Casa da Moura

\section{Nery Delgado, ein methodologischer Wegbereiter und seine Ausgrabungen in der Höhle von Casa da Moura in Portugal in 1879-1880}

Der Beitrag von Nery Delgado war maßgeblich für die Entwicklung von Ausgrabungstechniken auf urgeschichtlichen Fundstellen in Portugal, als die Disziplin am Ende des 19. Jahrbunderts in Europa 
aufblübte. Bei den Ausgrabungen der Höble von Casa da Moura (Óbidos, Portugal) in 18979-1880 führte er erstmals in Europa ein Rastersystem ein. Dieses Vermessungssystem teilte die Höble in achtundzwanzig Abschnitte auf; diese wurden unabhängig ausgegraben, und in jedem Abschnitt wurden alle Funde und Befunde vermessen und mit Angaben der Tiefe und der Abschnitte auf Etiketten registriert. Diese dreidimensionale Dokumentation gehört zu den ersten Versuchen, im späten 19. Jahrhundert Informationen über Kontext zu sammeln und ist eine sehr frühe Erscheinung von archäologischen Methoden, die heute weltweit angewendet werden. Somit war Nery Delgado ein Wegbereiter von modernen Ausgrabungsmethoden. Translation by Madeleine Hummler

Stichworte: Paläolithikum, Portugal, archäologische Ausgrabungen, Methodik, Nery Delgado, Casa da Moura

\section{Nery Delgado, pioneiro nos métodos de escavação arqueológica na Gruta da Casa da Moura, 1879-1880}

Nery Delgado foi uma figura chave no desenvolvimento dos métodos arqueológicos aplicados a sítios préhistóricos em Portugal, no contexto do desenvolvimento da arqueologia europeia no final do século XIX. Ele foi o primeiro na Europa a usar o método da quadrícula na escavação da Gruta Casa da Moura (Óbidos, Portugal) em de 1879-1880. A quadrícula dividia a gruta em vinte e oito setores, escavados independentemente e onde todos os achados arqueológicos e bioantropológicos foram inventariados e marcados com etiquetas onde aparece a informação da respetiva profundidade e unidade de escavação. Este método de registo tridimensional precedeu a adoção das técnicas de escavação de depósitos arqueológicos presentemente seguidas em todo o mundo. Deste modo, Nery Delgado foi um pioneiro das modernas práticas arqueológicas de campo, cuja importância só agora foi dada a conhecer. Translation by the authors.

Palavras-chave: Paleolítico, Portugal, Escavações arqueológicas, Métodos, Nery Delgado, Casa da Moura 